\title{
External and Internal Factors of the Turkish Crisis in the Year 2001 Analysis Proposal
}

\author{
Fatih Konak \\ Hitit University, Turkey \\ Hakan Turan \\ Hitit University, Turkey
}

\section{Introduction}

There has been much discussion on the issue of whether financial crisis are caused by external factors or internal factors. In this context, internal factors in economic crisis refer to the financial structure of a country, lack of monetary policy and so on. In addition, it has to be noted that these internal factors can be controlled and altered by the government of the country. In contrast, external factors represent to macroeconomic matters throughout the world, which cannot be controlled by the government of the country. In the case of Turkey, on the February 19, 2001, the Turkey economy was hit by massive financial crisis. In that time, overnight interest rates of the Central Bank of Turkey (CB) skyrocketed to 4059 percent in few days (Table 8), CB lost 7,5 billion dollars of reserves and the dollar exchange rate jumped from 685 thousand liras to 958 thousand liras (Fatih and Guven 2002). Therefore, the balance of Turkey economy was devastated and these conditions led the Turkey financial system to bankruptcy. Peter (2001) claimed that this crisis was the bankruptcy of the Turkey economy. Hence, it could be possible to state that it was the biggest financial crisis had been recorded in the Turkey economy history. Some economist blamed the Turkish financial crisis in 2001 was caused by the unfavourable changing in the world economy during the crisis period (Emre, 2001). According to Emre (2001), these external factors, which triggered the crisis, were: "the rise of the interest rates in the United States by 100 basis points, the increase in the international energy prices and the loss in the relative strength of the Euro vis-à-vis the US \$”. In addition, it can be added that the Russian economic crisis effects on the Turkey economy as an external factor (Ersan and Kenan, 1999), while other economist argue that the Turkish economy was overwhelmingly affected by internal factors (Emre, 2001). These internal factors behind the crisis namely dis-inflation programme, which was initiated in December 1999 backed and supervised by the International Monetary Fund (IMF), deficiencies and effects on the fragile banking system and financial environment, lack of fiscal discipline 
and monetary policy, also ruling out of structural reforms such as privatization, and seasonal factors, wrong monetary policy to finance the current account deficit and political crisis as a last shot (Emre,2001, Emre, Hakan and Kamuran, 2001, Ahmet and Erinc, 2002, Fatih and Guven, 2002). This essay argues that this crisis was overwhelmingly caused by internal factors because it could possible to eliminate the external factors effects on the economy with implementing right monetary and it could also possible that if a country's financial system is strong enough, it could protect itself from external attacks. However, some external factors also had an impact. In order to, demonstrate that this essay will first focus on the external factors behind the 2001 Turkish financial crisis. Having done that in the context of Turkey right before the crisis, the internal triggering factors will be presented. Moreover, this essay will endeavour to make contrast both of them with last global economic crisis effects, which boomed in the USA in the year 2008.

\section{Role of External Factors}

External factorsbehind the 2001 Turkish financial crisis can be examined under four main headings.

First, it is obvious that the USA economy is one of the most powerful economies in the world. Thus, other economies throughout the world are affected by tiniest variation in the USA economic indicators. One of them is the gradual interest rate (the federal interest rate). It refers to overnight borrowing by banks to maintain their bank reserves in the United States of America (Federal Reserve Bank of New York, 2007). This is an important development because, Eichengreen and Rose (1998) point out that highly significant coefficient between changes in industrialcountry such as America, interest rates and liquidity crisis in emerging market. Therefore this indicator should be monitored to determine monetary policy makers in order to avoid its bad effects on the economy by the economic policy makers. In the case of Turkey, during the year before the 2001 liquidity crisis, this rate was increased 125 basis point s (from 4,97\% to 6,24\% ) (Figure 1) so as to relieve the US economy by the Board of Governors of the Federal Reserve System (Emre,2001). Meanwhile the Turkish overnight interest rates was affected negatively and continued to go up due to this situation. It was dramatically increased from $45,6 \%$ to 62,5 . (Figure 2) As a result, it damaged the Turkish economy and triggered the 2001 economic crisis. This clearly shows that external factors are therefore relevant the 2001 crisis.

However, it can be argued that this external factor was not a big player behind the crisis. Because, in contrast, before the 2008 global financial crisis, which was considered to be the worst economic crisis worldwide since "the great depression". There was a considerable fluctuation in the FED Funds rates. For example, it was 
decreased from $6.24 \%$ to $1.13 \%$ between 2002 and 2004. (Figure 1) Nevertheless, after that it was went up sharply and reached to $5.02 \%$ just before the global financial crisis. In this context, the Central Bank of Turkey could achieve to keep the recovery policies, which included financial and banking sector's reforms, after the 2001 crisis period. Thus, at the same period, the overnight interest rate of Turkey was declined from $62,50 \%$ to $15,75 \%$ apart from small rise at the beginning of 2006 (Figure 2). Consequently, it is clear that FED Funds rates effects could be reduced by keeping the monetary policy. Therefore, it could be possible to state that external factors are not the relevant because their effects can be eliminated.

Secondly, it could be claimed that there was a significant link between rise in crude oil prices and the 2001 financial crisis in Turkey. Emre (2001) has drawn attention to the fact that in the case of Turkey, "crude oil is the most important imported input for production and consumption". It is clear that trade deficit, which refers to the amount by that merchandise imports exceed merchandise exports, could be affected negatively by this variation in crude oil prices. In this case, crude oil prices raised from US\$17,8 to US\$35 in 2000 (Figure 1). Thus, this exacerbated the problem of the trade deficit of Turkey (Table 2). In addition, the current account balance was affected negatively as well (Table 4). Because, the fact that the current account balance in the Turkey economy is mostly affected by changing energy prices (CB, Bulletin, 2009). Hence, this balance was devastated by this rise. As a result, it prepared a convenient ground for the liquidity crisis in 2001. Therefore, this clearly shows that there is an important relationship between the crisis and external factors.

On the other hand, in order to see the role of rising crude oil prices on the Turkish economy as a triggering factor, ten-year period after the 2001 financial crisis should be analyzed. There was a dramatic increase in crude oil price between early 2003 and 2007, and it reached the peak at almost $\$ 100$ (Figure 1). It is true that it affected the balance of foreign trade and either trade deficit or the current account deficit soared. However, the Turkish economy could keep the sustainable growth and also could reduce the effects of this augmentation because, monetary policy makers changed the financing the current account system (CB, Bulletin, 2007). In 2001, it was based on short- term capital which is so vulnerable. After that the government started to finance this deficit with long-term capital and direct investment (Figure 2). Therefore, it is clear that rise in crude oil price's effects would be reduced. This clearly shows that external factors are therefore not the most relevant. 
Thirdly, unfavourable change in US\$/EURO parity triggered the Turkish liquidity crisis in 2001 because turkey import depends on US\$ while export of Turkey EURO (Emre, 2001). As he points out "imports of raw materials and intermediary inputs are carried out in US\$, whereas export to the EURO zone (54\% of export in 1999 , especially to Germany which is very important trade partner) are carried out in EURO". Therefore, changing in this parity could affect the Turkey economy. In this case, the balance of foreign trade of Turkey was devastated. Moreover, this movement in US\$/EURO parity might have resulted in deterioration of current account deficit. Consequently, it is true that this variation triggered the crisis. This clearly shows that external factors are therefore relevant the 2001 crisis.

However, it has to be noted that the monetary policy makers of Turkey should have taken necessary measures in order to protect economy from unfavourable shock in this parity. Therefore, after the crisis, export and import inputs have been diversified to reduce unexpected variation in this parity. In this context, the Turkey government has developed trade relationship with different countries such as eastern, northern and Middle East countries. For example, the foreign trade volume has been increased from 6 billion \$ in 1998 to 52 billion \$ with countries, which are member of the Back Sea Economic Cooperative, so far. As a result, this external factor's effects have been eliminated.

Finally, the vulnerable financial structure of Turkey economy was affected by the Russian economic crisis, which had been caused by the Asian crisis by reducing the prices of raw materials and by disturbing confidence of foreign investors to Russian emerging capital market (Ersan and Kenan, 1999). As a result of these developments Russia faced a financial crisis in 1998. Ersan and Kenan (1999) claim that this crisis affected Turkish firms engaged in business and exports, luggage trade and tourism, which is the major revenue in the Turkey economy. They also note that the total loss of Turkey due to the Russian crisis amount for 3 billion dollars per year. Therefore, it can be claimed that it was the one of the most important external factors behind the 2001 liquidity crisis in Turkey.

In order to understand how the Russian economic crisis affected the Turkey economy, some data should be analyzed. The Turkish export to Russia had gone up from \$1442 million in 1992 to \$ 2057 million in 1997. However, the fall in Russian income due to the crisis, the Turkish export to Russia dropped $\$ 777$ million in 1998. Hence, the Turkey economy lost $\$ 1290$ million in a year (Table 1). Moreover, the Turkey economy's revenue from luggage trade with Russia and the number of tourists in Turkey from Russia dropped sharply from $\$ 8,842$ million and 1,256 (number in thousands) in 1996 to $\$ 3,689$ million and 326 (number in thousands) in 1998, respectively (Table 1). As a result, this crisis had raised the 
vulnerability of the Turkey economy. Therefore, it could be possible to state that Turkey economy affected external factors.

In contrast, in terms of the last global financial crisis (2008), the majority of the governments throughout the world have taken austerity measures in order to preserve themselves from the crisis wave. For example, the USA, the UK and other European countries such as Greece, have been attempting to cut spending to reduce the effects of the crisis (Yenigun, 2010). In this perspective, this movement affected the Turkey foreign trade especially rate of export, it dropped from $\$ 132$ billion in 2008 to approximately $\$ 102$ billion in 2009(Table 2). The total loss of Turkey economy was $\$ 30$ billion. However, the proportion of imports covered by exports rate increased from $65,4 \%$ to $72,5 \%$ at the same period. Consequently, it can be said that although the last global financial crisis was bigger than the Russian crisis, in terms of foreign trade, its effects on the Turkey economy was lower (Table 2). This clearly shows that external factors are therefore not the most relevant.

\section{Role of Internal Factors}

There were some external factors behind the 2001 Turkish liquidity crisis, even though internal factors the most relevant. In this perspective, Fatih and Guven (2002) has drawn attention the fact that the Turkish economy had been struggling the chronic inflation, which is one of the most important internal factors, for 25 years. Therefore, the monetary policy makers had implemented many stabilisation attempts, some of which have failed, in order to solve this problem (Emre, 2001). It is echoed by Ahmet and Erinc (2002), this program "exclusively relied on a nominally pegged exchange rate system for dis-inflation which has been major concern for Turkish policy makers for many years". In this case, before the Turkish liquidity crisis in 2001, Turkey initiated an extensive dis-inflation programme in December 1999 backed and supervised by the International Monetary Fund (IMF) (Ahmet and Erinc, 2002). As outlined in the Turkey letter of intent (1999), this programme aimed at fiscal adjustment, structural reform and privatization in Turkey economy. This letter also included significant measures to reinforce and regulate both the financial environment and banking sector of Turkey. However, this programme had many deficiencies on the implementation. For example, it just focused on reducing interest rate and inflation so that policy makers forgot the banking sector thus, this behaviour increased the vulnerability of the banking sector, and lack of monetary policy the Turkish government could not complete privatisation, which was very important in structural reform, and so on. As a result, it could not have been successful to prevent the internal factors effects so they 
triggered the crisis. Thus, this clearly shows that if the Turkish monetary policy makers had solved the internal problems, the crisis would not have boomed.

Initially, it could be possible to argue that the Turkish monetary policy makers should not have taken essential measures to protect economic stabilisation before the crisis. However, Ahmet and Erinc (2002) claim that throughout the first year of the dis-inflation programme, rule of this programme's were followed and the Central Bank of Turkey successfully controlled expansion of monetary base with its net domestic asset position within the programme limits. They also mentioned "the fiscal operations were in line both the revenue and expenditure targets". Nevertheless, the crisis conditions emerged in does course, primarily as a result of the increase fragility in financial system. According to Ahmet and Erinc (2002) "this fragility, in turn, was generated by the uncontrolled and excessively capital flow with exceedingly speculative component". In other words, this could be explained in this way, the Turkish economy had become more vulnerable to speculative capital flow because of liberalized capital account system which had been applied since 1989 due to this programme's permission to higher level of speculative capital inflow. Hence, this clearly shows that lack of monetary policy increased the economic crisis risk.

Ahmet and Erinc (2002) also claim that, in the context of the Turkish dis-inflation programme, dept financed public deficit and rapid acceleration of private expenditures increased inflow of short-term foreign capital. Therefore, the ratio short-term foreign dept to the Central Bank's reserves rose secularly throughout the programme. In this case, this ratio should have been the value of 60 percent because in terms of international speculation, its critical threshold is 60 percent (see e.g. Kaminsky, Lizondo and Reinhart,1998). It is obvious note that this ratio had never fallen below 100 percent since the liberalization system in Turkey, 1989. It means that the Turkish financial system had been operating consistently under the "danger zone" (Ahmet and Erinc, 2002). During the implementation of the disinflation programme, this ratio rose to 112 percent in June 2000 to 147 percent December 2000 (Table 3). Thus, it can be said that the programme increased the financial fragility and its liquidity creating mechanism did not allow for stabilisation. Therefore, it could be said that internal conditions were the most relevant.

Moreover, in the context of the Turkish banking system before the crisis, the banking sector's profit based on high inflation rates and real interest rate because no one believed that these rates could neither be reduced nor controlled (Emre, Hakan and Kamuran, 2001). Therefore, they organized all working plans to gain 
profit based on these rates. Demirguc and Huizinga (1999) concluded that in their analysis, the determinant of interest margins and profitability of banking sector, "higher inflation and real interest rates are associated with higher realized interest margins and profitability". They also found that "banking sectors with higher rates of concentration have higher margins and earn more profit". However, after the disinflation programme, inflation rate and interest rate started to decrease so that the Turkish banking sector changed their position towards to government debt instrument portfolio. It has to be noted that the quality of the government debt instruments portfolio is directly related to expectation regarding dept sustainability. Hence, Fatih and Guven (2002) argue that this feature increased the vulnerability of the system to concerns about the rollover it the outstanding government debt instruments because they also claimed that this portfolio in commercial bank balance sheets was even greater than loan portfolio. Consequently, this movement triggered the crisis under the uncertain financial environment in Turkey. Therefore, this clearly shows that if the government had realized the banking sector's this perilous movement timely, the crisis could have been prevented.

The other crucial internal factor behind the crisis is mid-sized banks in the banking system. Einchengreen (1998) argues that regarding the banking sector crisis which triggered the 2001 financial crisis, "the problem lied with a number of mid-sized banks". In addition, it ought to be noted that the Turkish government gave them bailout guarantee which means that when they are in the bankruptcy situation, their deposits and assets will be protected by the government (CB, Financial Stability Report, 2008). In fact, the majority of mid-sized banks were established because they relied on this guarantee (Fatih and Guven, 2002). According to Burnside, Enchenbaum and Rebelo (2001) "economic agents expect that these future deficit due to bailout guarantee, are going to be financed by many creation, which leads to a collapse of fixed exchange rate regime". Hence, it is clear that these banks damaged the Turkish banking system. Therefore, having been given permission to establish these kinds of banks in the Turkish banking sector, and lack of controlling of these banks' financial structure, led the Turkey economy into the crisis.

Furthermore, The Banks Association of Turkey's data showed that before the 2001 crisis, Turkey have 84 banks. However, during the crisis period 37 mid-sized banks were bailout and the number of banks in the Turkish banking sector decreased to 47 (BRSA, 2010). Failure of these banks brought massive amount of $\$$ billion financial burden on the Turkey economy. Therefore, this circumstance led the Turkey economy into worse condition. However, it should be noted that after the crisis, Turkish banking sector has grown under the control of the Banking Regulation and Supervision institute which was established in the year 2000 
(Tevfik,2010). This institute reduced the number of mid-sized banks and controlled the bank's balance sheets in order to keep the sustainable growth. As a result, many banks have bankrupted in the USA after the global crisis. Despite this fact there is no bank has bankrupted. Therefore, this clearly shows that if the banking sector is controlled in right way, in other words, if the fragility of the banking sector is solved, the economy can be protected from the crisis.

On the privatisation front, the Turkish monetary policy makers were planning to make money from privatisation under the control of IMF so as to decrease budget deficit and increase the investments. However, Emre (2001) has drawn attention the fact that "instead of the privatisation receipt target value of US\$7, 5 billion only US\$3, 5 billion was realized throughout 2000". This development showed that the Turkish authority went out of the programme. Therefore, they could not meet the target. As a result, their finance plan was devastated. In contrast, after the crisis, the Republic of Turkey Prime Ministry Privatisation Administration's data indicates that the government has made almost $\$ 25$ billion revenue from privatisation so that they could use this money to protect economy (Table 7). Hence, following the monetary policy rules is very important. In this perspective, if it is not followed, it could trigger the crisis.

Besides, one of the most important triggering factors behind the crisis is the current account deficit. It reached the peak before the crisis at $-9,92$ in 2000. Therefore, all economic predictions were damaged by this augmentation. However, it could be argued that the problem was not just current account deficit. The real problem was in how to finance it. Current account deficit was overwhelmingly financed with short-term capital in that year (Figure 2). Hence, when the short-term capital float from the country, it could not be financed consequently the problem become bigger. Turkey had same situation in the crisis year. On the other hand, although in the year 2007 the current account deficit was higher than used to be, the Turkey economy was not damaged because it was financed with long-term capital and foreign direct investment, which are more durable than short-term capital. it stated in the CB bulletin (March 2009) that "long-term capital and foreign direct investment have significant impact in terms of the financing quality of the current account deficit, and they reduce the degree of vulnerability of the economy". As a result, it can be said that the current account might not be a big problem, if it is financed in right way (Table 4).

Another important internal reason in the crisis is lack of monetary policy. For example, monetary policy makers ruled out the seasonal factors such as common in finance literature the so-called "January affect" which refers to outflow of the 
capital from a country in order for avoiding tax liability. In the case of Turkey, according to Emre (2001) stated that although the Central Bank of Turkey is able to sterilize the effects of this seasonal outflow, it operated like a quasi-currency board and ruled out the possibility of unfavourable effects on the fragile finance and banking system structure due to such outflow. As a consequence, it is clear that policy makers always have to prepare themselves to these kinds of effects. Otherwise, financial environment could not be protected like in Turkish crisis case. This clearly shows that lack of monetary policy is therefore the one of the most relevant internal factors behind the crisis.

It could be stated that political stability is one of the most significant indicators for financial environment in order to sustain and keep their position. In this case, on the 19 of February in 2001, after the National Security Council meeting, the Prime Minister Bülent Ecevit declared that there was a deep difference opinion between him and President A.Necdet Sezer. He also added that it was a very important political crisis. This declaration was not estimated in the uncertain financial environment. Therefore, after this announcement, Fatih and Guven (2002) stated that overnight interest rate skyrocketed to 4019 in two days, and the Central Bank lost 7, 5 billion dollars of reserve thus, the $\mathrm{CB}$ had to accept the collapse of crawling peg exchange system and the Lira would be going to freely float so that the dollar exchange rate jumped to 958 thousand liras from a level of 685 thousand liras. Consequently, the Turkey economy slid into a massive crisis. This clearly shows that if this political instability had not been occurred, the financial crisis could have been obstructed. Therefore, it was relevant internal factor behind the crisis.

\section{Conclusion}

In conclusion, this essay has attempted to demonstrate what were the real reasons, which were divided into two section; internal and external factors that have been already mentioned above, behind the Turkish financial crisis in 2001. The crucial question that demands an answer is 'which one of them overwhelmingly triggered the crisis. On the one hand, it has argued that before the crisis boomed, the Turkey economy had been affected by some unfavourable external shocks such as, rise in crude oil prices, which increased the current account deficit; however, it can be seriously solved by employing correct finance technique that using long-term capital and direct investment instead of short-term capital. Therefore, it can be clearly seen that external factors effects on the economy can be eliminated by right monetary policy. On the other hand, it can be stated that there were many internal factors behind the crisis such as fragile finance and banking system, ruling out disinflation negative effects and seasonal factors and so on. It could be advocated that 
these factors led the turkey economy into uncertain situation and they had central part in the crisis because, after the crisis, they had been solved so the Turkey economy had become stronger. Consequently, it was not be affected by the last global financial crisis (2008) which soared the all unexpected external factors. It can be said that if an economy is strong enough, the external factors are not big problems. However, due to occurance of different types of crises, the limitation of this study is appeared. In other words, different circumstances can affect a country's economy which is vulnerable.It can be recommended for future studies that country's specific conditions should not be forgotten during analysis.

\section{References and notes:}

Alper, C.Emre (2001) "The Turkish Liquidity Crisis of 2000: What Went Wrong..., Forthcoming: Russian and East European Finance and Trade, vol. 37, no. 6, November-December 2001, pp. 51-71

Alper, C. Emre, Berument, M. Hakan and Malatyali, N.Kamuran (2001) "The Effect of the Disinflation program on the Structure of the Turkish Banking Sector", Russian and East European Finance and Trade, vol. 37, no. 6, Novvember-December 2001, pp. 81-95

Bilgin Tevfik Head of BRSA (2010) Available at: http://www.stratejikboyut.com/haber/ turkiye-bankacilikta-nereden-nereye--32378.html

Bocutoglu, E. and Celik, K. (1999) "The Effects of Russian Economic Crisis on Turkish Economy: A Brief Assessment" Karadeniz Technical University

BRSA (2010) Files of excel about the Turkish Banks Available at: http://www.tbb.org.tr/ tr/Banka_ve Sektor_Bilgileri/ Tarihsel_Bilgiler.aspx

Burnside, C., Einchenbaum, M. and Rebelo, S. (2001) "Prospective deficits and the Asian Currency Crisis”, Journal of Political Economy, 109(6), 1155-1197

CB Financial Stability Report (November 2008) Available at: http://www.tcmb.gov.tr/

Central Bank of the Republic of Turkey Bulletin March 2009 Issue: 13

Central Bank of the Republic of Turkey Bulletin December 2007 Issue: 8

Demirguc-Kunt, A and H. Huizinga (1999) Determinants of Commercial Bank Interest Margins and Profitability: Some International Evidence" World Bank Economic Review 13, no. 2: 379-408

Einchengreen, B., and A. Rose (1998) "Staying Afloat When the Wind Shifts: External Factors and Emerging-Market Banking Crisis." National Bureau of Economic Research, Working Paper No. 6370

Ertugrul, Ahmet and Yeldan, Erinc (1999), “On the Structural Weaknesses of the Post- 1999 Turkish Dis-Inflation Program"

Einchengreen, B., and A.Rose (1998) "Staying Afloat When the Wind Shifts: External Factors and Emerging-Market Banking Crisis." National Bureau of Economic Research, Working Paper No. 6370

Federal Reserve Bank of New York (2007) "Fed Point” Available at:

http://www.newyorkfed.org/aboutthefed/ fedpoint/fed15.html

Ozatay, Fatih and Guven, Sak (2002)“ The 2000-2001 Financial Crisis in Turkey”, Central Bank of Turkey and Ankara University

Tsagaris, Peter (2001) “Turkey’s Crisis” International Socialist Review 
Yenigun (2010) “Avrupa Ekonomisinin Dizginleri El Arıyor”, Haber Güncel, Available at :http://www.as-add.de/haber/guencel/3839-avrupa-ekonomisinin-dizginleri-el-aryor.html.1999“Turkey Letter of Intent” International Monetary Fund, Washington, DC, www.imf.org/external/np/ loi/1999/120999.htm, December

\title{
Summary
}

\section{External and Internal Factors of the Turkish Crisis in the Year 2001. Analysis Proposal}

\author{
Fatih Konak \\ Hitit University, Turkey \\ Hakan Turan \\ Hitit University, Turkey
}

This research has attempted to demonstrate what were the real reasons whether internal or external factors, behind the Turkish financial crisis in 2001. The Turkey economy had been affected by some unfavourable external shocks such as, rise in crude oil prices which increased the current account deficit. However, external factors effects on the economy can be eliminated by right monetary policy. On the other hand, there were many internal factors behind the crisis such as fragile finance and banking system, ruling out dis-inflation negative effects and seasonal factors and so on. It could be advocated that these factors led the Turkish economy into uncertain situation because, when the last global financial crisis was occurred in 2008, although all unexpected external factors were soared, the Turkish economy was less affected, because the Turkish economy has been become more durable by solving the internal triggering factors.

Key Words: Economic Crisis, the Turkish Financial Crisis In 2001 JEL Codes: G00, G01 


\section{APPENDIX}

Figure 1: The Trend of Crude Oil Prices

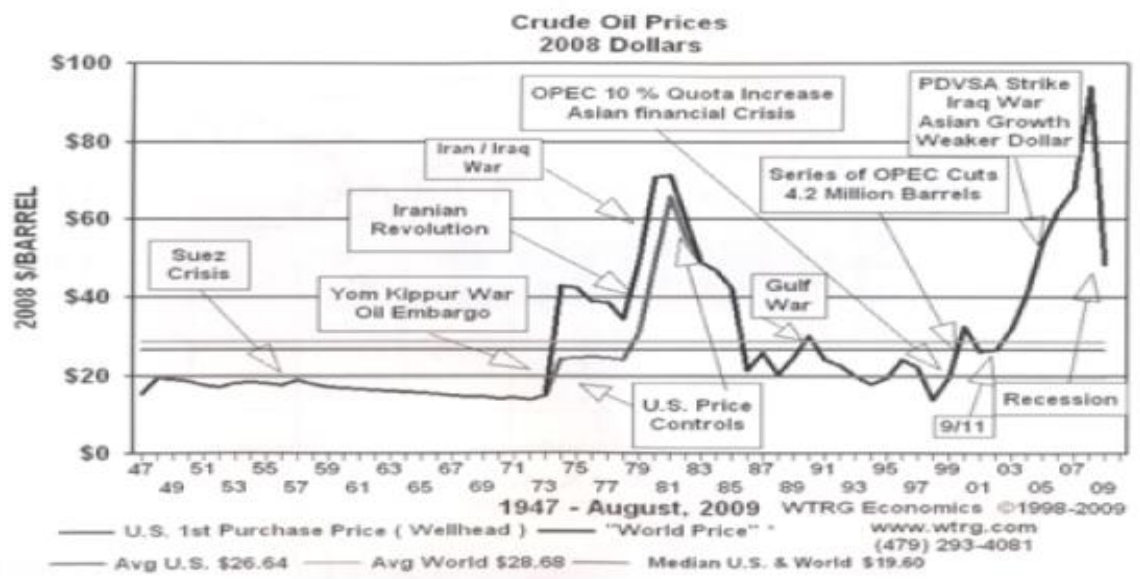

Source:http://www.tcmb.gov.tr/wps/wcm/connect/TCMB+TR/TCMB+TR/Main+ Menu/Yayinlar/Raporlar

Figure 2: The History of Current Account Deficit in Turkey

Financing of Current Account Deficit (12 month cumulative, percent)

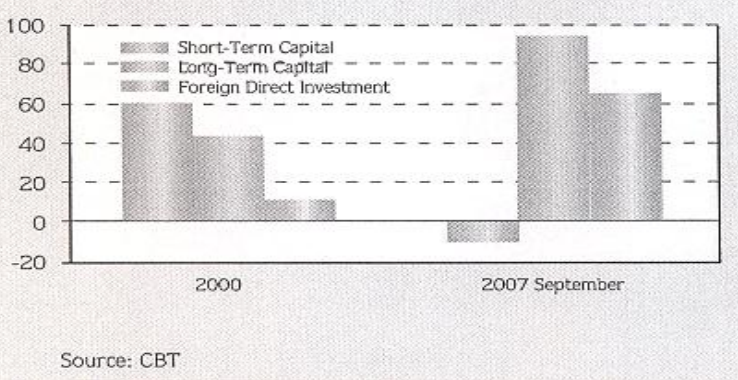

Source:http://www.tcmb.gov.tr/wps/wcm/connect/TCMB+TR/TCMB+TR/Main+ Menu/Yayinlar/Raporlar 
Table 1:Turkish Foreign Trade, Turkish Revenues from The Luggage Goods Trade with Russia and The Number of Tourists in Turkey from Russia

Turkish Foreign Trade with Russia (in million dollars)

\begin{tabular}{|c|c|c|c|c|}
\hline$\underline{\text { Years }}$ & $\underline{\text { Exports (fob) }}$ & Imports & $\underline{\text { Total }}$ & Balance \\
\hline 1992 & 442 & 1036 & 1478 & -594 \\
\hline 1993 & 499 & 1542 & 2041 & -1043 \\
\hline 1994 & 820 & 1046 & 1866 & -226 \\
\hline 1995 & 1232 & 2082 & 3314 & -850 \\
\hline 1996 & 1512 & 1921 & 3433 & -409 \\
\hline 1997 & 2057 & 2174 & 4231 & -117 \\
\hline 1997 & 914 & 1018 & 1932 & -104 \\
\hline 1998 & 777 & 1071 & 1848 & -294 \\
\hline
\end{tabular}

Turkish Revenues from The Luggage Goods Trade with Russia (million dollars)

\begin{tabular}{|l|l|}
\hline 1996 & 8842 \\
\hline 1997 & 5849 \\
\hline 1998 & 3689 \\
\hline
\end{tabular}

\section{Source:}

1) Turkish State Institute of Statistics

(http://www.dpt.gov.tr/tptweb/ekutup98/rusya/kriz.html)

2)Turkish State Planning Organization (http://www.dpt.gov.tr/dptweb/ekutup98/rusya/kriz.html)

3) Central Bank of Turkey (http://www.tcmb.gov.tr/)

4)Turkish State Planning Organization http://www.dpt.gov.tr/dptweb/ekutup98/rusya/kriz.html

Table 3The Number of Tourists in Turkey from Russia

\begin{tabular}{|l|l|l|l|l|l|l|}
\hline & \multicolumn{2}{|l|}{1996} & 1997 & \multicolumn{1}{l|}{1998} \\
\hline Countries & $\begin{array}{l}\text { Number in } \\
\text { thousand }\end{array}$ & $\begin{array}{l}1 \\
\%\end{array}$ & $\begin{array}{l}\text { Number in } \\
\text { thousand }\end{array}$ & $\begin{array}{l}2 \\
\%\end{array}$ & $\begin{array}{l}\text { Number in } \\
\text { thousand }\end{array}$ & $\begin{array}{l}3 \\
\%\end{array}$ \\
\hline Russia & 1256 & 4 & 1017 & 5 & 326 & 6 \\
\hline
\end{tabular}

\section{Source:}

1) Turkish State Institute of Statistics

(http://www.dpt.gov.tr/tptweb/ekutup98/rusya/kriz.html)

2)Turkish State Planning Organization (http://www.dpt.gov.tr/dptweb/ekutup98/rusya/kriz.html)

3) Central Bank of Turkey (http://www.tcmb.gov.tr/)

4)Turkish State Planning Organization http://www.dpt.gov.tr/dptweb/ekutup98/rusya/kriz.html 
Table 2:Turkish Foreign Trade by Years

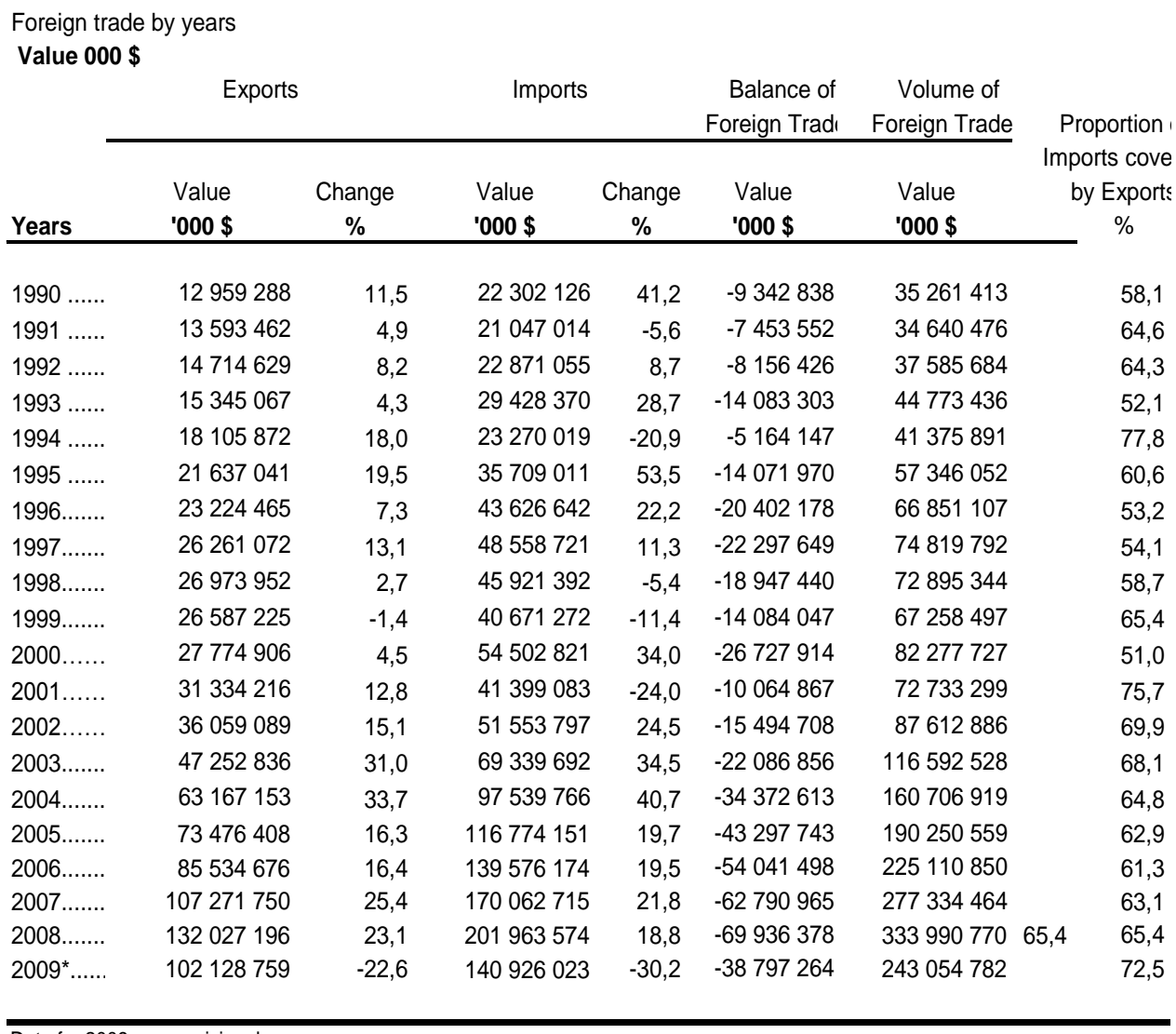

Data for 2009 are provisional.

\section{Source:}

http://www.tuik.gov.tr/Start.do;jsessionid=LhvcJ28pTdhGcrW7nLd9QXmSKQMl Gyl4GwRyV42rsSY1mtHD1Xpj!-2035832961

Table 3: Turkish Current Account Balances by Years(Billion USD)

\begin{tabular}{|l|l|l|l|l|l|l|l|l|l|}
\hline $\mathbf{1 9 8 4}$ & $-1,4$ & $\mathbf{1 9 8 9}$ & 0,9 & $\mathbf{1 9 9 4}$ & 2,6 & $\mathbf{1 9 9 9}$ & $-0,9$ & $\mathbf{2 0 0 4}$ & $-14,4$ \\
\hline $\mathbf{1 9 8 5}$ & $-1,0$ & $\mathbf{1 9 9 0}$ & $-2,6$ & $\mathbf{1 9 9 5}$ & $-2,5$ & $\mathbf{2 0 0 0}$ & $-9,9$ & $\mathbf{2 0 0 5}$ & $-22,1$ \\
\hline $\mathbf{1 9 8 6}$ & $-1,5$ & $\mathbf{1 9 9 1}$ & 0,3 & $\mathbf{1 9 9 6}$ & $-2,4$ & $\mathbf{2 0 0 1}$ & 3,8 & $\mathbf{2 0 0 6}$ & $-32,1$ \\
\hline $\mathbf{1 9 8 7}$ & $-0,8$ & $\mathbf{1 9 9 2}$ & $-1,0$ & $\mathbf{1 9 9 7}$ & $-2,6$ & $\mathbf{2 0 0 2}$ & $-0,6$ & $\mathbf{2 0 0 7}$ & $-38,2$ \\
\hline $\mathbf{1 9 8 8}$ & 2,6 & $\mathbf{1 9 9 3}$ & $-6,4$ & $\mathbf{1 9 9 8}$ & 2,0 & $\mathbf{2 0 0 3}$ & $-7,5$ & $\mathbf{2 0 0 8}$ & $-41,4$ \\
\hline
\end{tabular}

Source:http://www.tcmb.gov.tr/wps/wcm/connect/TCMB+TR/TCMB+TR/Main+

Menu/Istatistikler/Parasal+ve+Finansal+Istatistiklr 
Table 4: Interests Rates and Exchange Rates on February 2001

Balance sheet of the Central Bank, interest rates, and exchange rate in the second attack period, February 2001

\begin{tabular}{|c|c|c|c|c|c|c|c|}
\hline & $\begin{array}{l}\text { Net domestic assets }{ }^{a} \\
\text { (Trillion Lira) }\end{array}$ & $\begin{array}{l}\text { Net foreign assets } \\
\text { (Trillion Lira) }\end{array}$ & $\begin{array}{l}\text { Base money } \\
\text { (Trillion Lira) }\end{array}$ & $\begin{array}{l}\text { Reserves }^{\mathrm{d}} \\
\text { (Million \$) }\end{array}$ & $\begin{array}{c}\text { Overnight rate }^{\theta} \\
(\%)\end{array}$ & $\begin{array}{c}\text { Bond rate } \\
(\%)\end{array}$ & $\begin{array}{c}\text { Exchange rate } \\
\text { (\$/Lira) }\end{array}$ \\
\hline February 15 & -1754 & 6680 & 4927 & 28217 & 39.2 & 61.9 & 682686 \\
\hline 16 & -1547 & 6649 & 5102 & 27943 & 40.3 & 63.4 & 685998 \\
\hline 19 & -1626 & 6708 & 5082 & 28105 & 43.7 & 67.9 & 685039 \\
\hline 20 & -1300 & 5687 & 4387 & 26739 & 2057.7 & 25514.7 & 683074 \\
\hline 21 & 868 & 3417 & 4286 & 23207 & 4018.6 & 150.2 & 688001 \\
\hline 22 & 2070 & 3373 & 5443 & 23267 & 1195.3 & 147.7 & 685391 \\
\hline 23 & 1560 & 4198 & 5758 & 22581 & 568.0 & 195.8 & 957879 \\
\hline 26 & 1205 & 4046 & 5251 & 21988 & 102.1 & 145.3 & 1072988 \\
\hline 27 & 1659 & 3311 & 4970 & 21699 & 100.2 & 168.7 & 946306 \\
\hline 28 & 2156 & 2915 & 5071 & 21432 & 100.1 & 245.3 & 906164 \\
\hline
\end{tabular}

a: Net domestic assets = Credit to public sector + government securities + credit to banking sector - public sector deposits + other

b: Net foreign assets = Foreign assets - foreign exchange liabilities to non-residents - foreign exchange liabilities to banking sector

c: Base money $=$ Net domestic assets + net foreign assets

d: Reserves: International reserves

e: Overnight rate is the weighted average uncompounded rate.

$\mathrm{f}$ : Bond rate is the compounded average secondary market rate.

Source: Central Bank

Source: $\quad$ http://www.tcmb.gov.tr/wps/wcm/connect/TCMB+TR/TCMB+TR/

Main+Menu/Istatistikler 